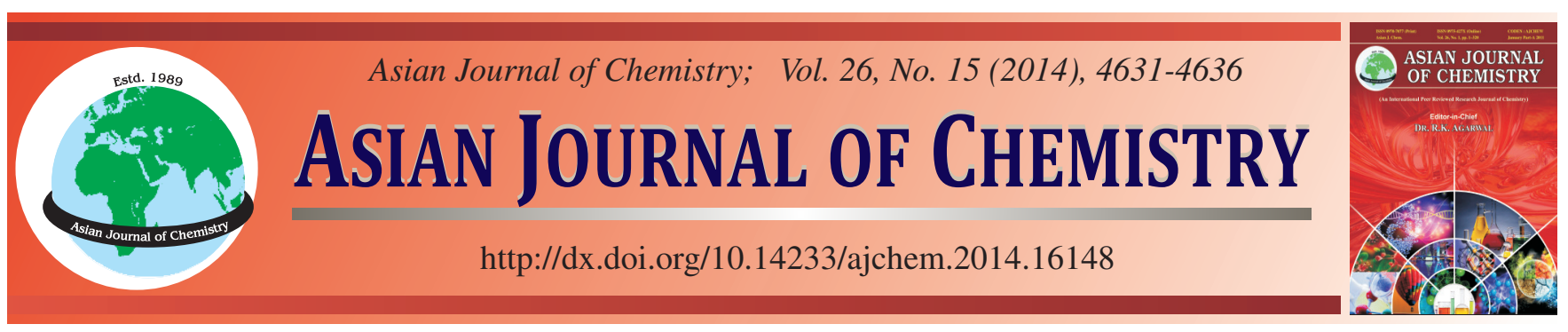

\title{
Effects of Carbon Sources on Heterotrophic Nitrification and Glyoxylate Cycle by Alcaligenes faecalis $\mathbf{C 1 6}$
}

\author{
HuA An, YuXiang Liu* and YaO WAng
}

College of Environmental Science and Engineering, Taiyuan University of Technology, Taiyuan 030024, Shanxi Province, P.R. China

*Corresponding author: Tel: +86 18635150467; E-mail: 18635150467@163.com

To obtain a better insight into the relationship between heterotrophic nitrification and glyoxylate cycle by heterotrophic nitrification bacterium, the two key enzymes of glyoxylate cycle, the ammonium removal ability, and the specific nitrifying activity of Alcaligenes faecalis $\mathrm{C} 16$ grew with different carbon sources were examined. The growth and ammonium removal ability of heterotrophic nitrification bacterium are strongly influenced by carbon sources, as well as the activities of key enzymes of glyoxylate cycle. Strain C16 grew best in the medium with fumaric acid, and failed to grow on the medium with sucrose, glycerol, glucose or ethanol as sole carbon source. There was a well correlation between the ammonium removal rate and the growth of heterotrophic nitrification bacterium. The strain C16 showed the most activities of isocitrate lyase and malate synthase when the ammonium removal rate reached highest. The results showed that the ammonium removal rate is strictly dependent on the growth of heterotrophic nitrification bacterium, and the growth of strain was strongly influenced by the glyoxylate cycle, the positive correlation relationship was found between the glyoxylate cycle and nitrification.

Keywords: Heterotrophic nitrification, Glyoxylate cycle, Isocitrate lyase, Malate synthase, Nitrifying activity.

\section{INTRODUCTION}

Nitrification is a microbial process that the ammonium is oxidized to nitrite by microbial in aerobic condition and then further oxidized to nitrate ${ }^{1,2}$. The therory of heterotrophic nitrification brought a more richer cognition for biological denitrification $^{3}$, which is thought to be performed in a similar mode with autotrophic process ${ }^{1}: \mathrm{NH}_{4}{ }^{+}-\mathrm{N}$ is converted to $\mathrm{NH}_{2} \mathrm{OH}$ by ammonia monooxygenase (Amo), and then $\mathrm{NH}_{2} \mathrm{OH}$ is oxidized to $\mathrm{NO}_{2}^{-}$by hydroxylamine oxidoreductase (HAO), and then $\mathrm{NO}_{2}^{-}$is oxidized to $\mathrm{NO}_{3}^{-}$. There are some heterotrophic microorganisms grow with nitrification. Among them are several fungi, actinomycetes and bacteria. They can use different kinds of organic and inorganic substances as $\mathrm{N}$-source for nitrification to produce nitrite or nitrate $e^{4,5}$. Most fungi excrete mainly nitrate, while most bacteria and actinomycetes main product nitrite. While there are several denitrifying bacteria $^{1,6,7}$, they can denitrify their nitrification products. In this case, $\mathrm{NO}_{3}^{-}$and $\mathrm{NO}_{2}^{-}$are reduced to $\mathrm{NO}_{2}^{-}$and $\mathrm{N}_{2}$ by nitrate reductase (NR) and nitrite reductase (NIR), respectively. Nitrification and denitrification are not only important for maintaining the global environment ${ }^{8}$, but also a theoretical foundation for nitrogen removal of wastewater biological treatment ${ }^{9}$. Ammoniam treatment is an essential key step for sewage treatment to preventing eutrophication caused by the nitrogen. Compared with autotrophic nitrifying bacteria in the traditional wastewater treatment process, the heterotrophic nitrifying bacteria show a higher growth rate and more adaptation in the different environments, which presents an unique advantages for wastewater treatment ${ }^{10,11}$.

The glyoxylate cycle, which was first proposed by Kornberg and $\mathrm{Krebs}^{12,13}$ in bacteria growing on acetate ${ }^{9}$, is an anaplerotic metabolic pathway which plays an important role in the biogenesis of carbohydrates from $\mathrm{C} 2$ compounds $^{3,4}$. There are two key specific enzymes in the glyoxylate cycle, isocitrate lyase (ICL;EC4.1.3.1) and malate synthase (MS;EC2.3.3.9) ${ }^{12}$. Isocitrate lyase, catalyzing the cleavage of D-isocitrate to glyoxylate and succinate; and malate synthase, catalyzing the formation of L-malate from glyoxylate and acetyl-CoA ${ }^{14}$. This pathway is widespread in living organisms, including bacteria, fungi, plants and even animals, and is of vital importance for the carbohydrates synthesis of organisms ${ }^{15,16}$.

Carbon source is necessary for the growth and metabolism of microorganisms, and provide the material basis for normal growth and division of cells. Many studies have been done on the influence of carbon source on the heterotrophic nitrifying bacteria. For example, Aspergillus niger can make full use of soluble starch, glucose, sucrose and maltose, while poor utilization of lactose, and hardly use of $\beta$-cyclodextrin as carbon source ${ }^{17}$; glucose was the optimal carbon source of 4 kinds of 
NDPAOs ${ }^{18}$; Arthrobacter sp. 9006 grew with a wide variety of organic carbon source, but the organism formed nitrite from ammonium only when citrate, malate, ethyl acetate or ethanol as carbon source ${ }^{4}$; the nitrifying activity of Alcaligenes faecalis OKK17 was high when pyruvate and oxaloacetate as the sole carbon $^{19}$. However, little is known on the in vivo response of bacterias under different carbon sources. Less attention has been paid to the glucose metabolism affected by different carbon sources of the bacterial.

To date, there has only been scarce evidence for the relationship between the activity of the key enzymes in the glyoxylate cycle and the efficiency of ammonia nitrogen removal rates in heterotrophic microorganisms. For our experiment, we use the heterotrophic nitrification bacterium, Alcaligenes faecalis $\mathrm{C} 16$, which was isolated from the activated sludge of coking wastewater treatment. Some strains of Alcaligenes faecalis are repoted about the ability of nitrification and denitrification ${ }^{1,20,21}$, however, the strain $\mathrm{C} 16$ showed a high ammonium removal rate with specific carbon source ${ }^{22,23}$. In this study, we characterized the glyoxylate cycle enzymes in Alcaligenes faecalis $\mathrm{C} 16$ under different conditions with a wide variety of organic carbon sources, and detected the excess ammonium in the medium and the activity of nitrification and denitrification, to obtain a better insight into a possible explanation for the different nitrification patterns during growth is based on the regulation properties of glyoxylate cycle enzymes.

\section{EXPERIMENTAL}

Culture conditions and cell extracts: A. faecalis $\mathrm{C} 16$ was obtained from coking wastewater and grown under aerobic conditions at $30^{\circ} \mathrm{C}$, and in a chemically defined medium contained ( $\mathrm{g} / \mathrm{L}$ distilled water): 4.902 sodium acetate $\cdot 2 \mathrm{H}_{2} \mathrm{O}$ as sole carbon source, $0.472\left(\mathrm{NH}_{4}\right)_{2} \mathrm{SO}_{4}, 0.05 \mathrm{MgSO}_{4} \cdot 7 \mathrm{H}_{2} \mathrm{O}, 0.2$ $\mathrm{K}_{2} \mathrm{HPO}_{4}, 0.12 \mathrm{NaCl}, 0.01 \mathrm{MnSO}_{4} \cdot 4 \mathrm{H}_{2} \mathrm{O}, 0.01 \mathrm{FeSO}_{4} \cdot 7 \mathrm{H}_{2} \mathrm{O}$, pH 7.0 (According to Stephenson medium ${ }^{10,24}$ ). The medium was autoclaved for $20 \mathrm{~min}$ at $121{ }^{\circ} \mathrm{C}$.

For experiments with washed cell suspensions, the cell were grown in $500 \mathrm{~mL}$ Erlenmeyer flasks containing $200 \mathrm{~mL}$ of medium above ( $1 \%$ of the cell inoculum) at $30{ }^{\circ} \mathrm{C}$ on a rotary shaker at $120 \mathrm{rpm}$, harvested under sterile conditions in the logarithmic growth phase by centrifugation (10 $\mathrm{min}, 8000$ $\times \mathrm{g})$, washed three times with tris $-\mathrm{HCl}$ buffer $(0.05 \mathrm{M}, \mathrm{pH}$ 7.7), and resuspended in $5 \mathrm{~mL}$ of the same buffer, lysed by sonication in a bath of ice. Cell debris was removed by centrifugation ( $20 \mathrm{~min}, 15000 \times \mathrm{g}, 4^{\circ} \mathrm{C}$ ), and supernatant was used for enzyme assays.

Enzyme assays and determination of protein concentration: Isocitrate lyase activity was measured according to Mcfadden and Ching ${ }^{25-27}$. ICL reaction, the cleavage reaction of isocitrate to succinate and glyoxylate, was assayed by measuring the formation of glyoxylate phenylhydrazine in the presence of isocitrate and dinitrophenylhydrazine at $30{ }^{\circ} \mathrm{C}$. The reaction mixture contained $0.05 \mathrm{M}$ tris- $\mathrm{HCl}$ buffer $(\mathrm{pH}$ 7.7), $150 \mathrm{mM} \mathrm{MgSO}_{4}, 60 \mu \mathrm{M}$ L-CysteineHCl, $7 \mathrm{mM}$ D-isocitrate, and enzyme solution. The reaction was started by the addition of D-isocitrate, and stopped by the addition of $10 \%$ trichloroacetic acid. $0.1 \%$ dinitrophenylhydrazine and $1.5 \mathrm{M}$
$\mathrm{NaOH}$ were added to the reaction solution. The activity was detected according to the rate of formation of glyoxylate phenylhydrazine in absorbance at $445 \mathrm{~nm}$. One unit (U) of enzyme activity is defined as the amount of enzyme necessary to produce $1 \mu \mathrm{mol}$ of glyoxylate phenylhydrazine per minute under assay conditions.

Malate synthase activity was measured according to $\mathrm{Cook}^{28}$. MS reaction, the synthesis reaction of acetyl-CoA and glyoxylate to L-malate, was assayed by measuring the degradation of acetyl-CoA at $30{ }^{\circ} \mathrm{C}$. The reaction mixture of $1 \mathrm{~mL}$ volume consisted $100 \mathrm{mM}$ tris- $\mathrm{HCl}$ buffer ( $\mathrm{pH} 8.0), 10 \mathrm{mM}$ $\mathrm{MgCl}_{2}, 1 \mathrm{mM}$ glyoxylate, $150 \mu \mathrm{M}$ acetyl-CoA, and the enzyme solution. The reaction was started by the addition of acetylCoA. The activity was detected according to the rate of degradation of acetyl-CoA in absorbance at $232 \mathrm{~nm}$. One unit (U) of enzyme activity is defined as the amount of enzyme necessary to consume $1 \mu \mathrm{mol}$ of acetyl-CoA per minute under assay conditions.

Hydroxylamine oxidoreductase activity was measured according to Zhao et $a l .{ }^{29}$. HAO reaction, the oxidation of $\mathrm{NH}_{2} \mathrm{OH}$ to $\mathrm{NO}_{2}^{-}$, was assayed by measuring the degradation of ferricyanide. The reaction mixture contained $0.05 \mathrm{M}$ tris$\mathrm{HCl}$ buffer (pH 7.4), $10 \mathrm{mM}$ ferricyanide, $4 \mathrm{mM}$ EDTA, and enzyme solution. The reaction was started by the addition of $2 \mathrm{mM} \mathrm{NH}_{2} \mathrm{OH}$. The activity was detected according to the rate of degradation of ferricyanide in absorbance at $400 \mathrm{~nm}$. One unit (U) of enzyme activity is defined as the amount of enzyme necessary to consume $1 \mu \mathrm{mol}$ of ferricyanide per minute under assay conditions.

Nitrate reductase activity was measured according to Zhao et al. ${ }^{29}$. NR reaction, the reduction of $\mathrm{NO}_{3}{ }^{-}$to $\mathrm{NO}_{2}^{-}$, was assayed by measuring the degradation of $\mathrm{NO}_{3}{ }^{-}-\mathrm{N}$. The reaction mixture contained $10 \mathrm{mM}$ potassium phosphate buffer ( $\mathrm{pH} 7.4$ ), 0.2 mM NADH, and enzyme solution. The reaction was started by the addition of $10 \mu \mathrm{M} \mathrm{NaNO}$. The activity was detected according the rate of degradation of $\mathrm{NO}_{3}{ }^{-}-\mathrm{N}$ in absorbance at $340 \mathrm{~nm}$. One unit (U) of enzyme activity is defined as the amount of enzyme necessary to consume $1 \mu \mathrm{mol}$ of $\mathrm{NO}_{3}{ }^{-}$-N per minute under assay conditions.

Nitrite reductase activity was measured similar with nitrate reductase. NIR reaction, the reduction of $\mathrm{NO}_{2}^{-}$to $\mathrm{N}_{2}$. The reaction mixture contained same with $\mathrm{NR}$ reaction. And the reaction was started by the addition of $10 \mu \mathrm{M} \mathrm{NaNO}$. The activity was detected according the rate of degradation of $\mathrm{NO}_{2}{ }^{-} \mathrm{N}$ in absorbance at $340 \mathrm{~nm}$. One unit (U) of enzyme activity is defined as the amount of enzyme necessary to consume $1 \mu \mathrm{mol}$ of $\mathrm{NO}_{2}^{-}-\mathrm{N}$ per minute under assay conditions.

Protein concentration was determined by the Bradford Reagent Kit (Sangon, Shanghai) ${ }^{29}$.

Chemical analysis: Growth of the bacterium was monitored by measuring the optical density $\left(\mathrm{OD}_{600}\right)$ using a spectrophotometer at $600 \mathrm{~nm}$. Ammonium analysis was performed by the method of Nessler'reagent photometry ${ }^{30}$, containing $25 \mathrm{~mL}$ culture supernatant mixed with $500 \mu \mathrm{L}$ potassium sodium tartrate and $750 \mu \mathrm{L}$ Nessler'reagent,measuring the concentrations of ammonium $\left(\mathrm{NH}_{4}{ }^{+}-\mathrm{N}\right)$ at $420 \mathrm{~nm}$ after $10 \mathrm{~min}$ against a blank with distilled water treated as above. 


\section{RESULTS AND DISCUSSION}

Properities of isocitrate lyase and malate synthase: Isocitrate lyase and malate synthase activities were measured in cell extracts of A. faecalis $\mathrm{C} 16$ grown in chemically defined medium according to stephenson medium with sodium citrate as sole carbon source. To find the influence on the glyoxylate cycle by different conditions. The main characteristics of isocitrate lyase and malate synyhase from A. faecalis $\mathrm{C} 16$ are shown in Table-1.

\section{TABLE-1}

CHARACTERIZATION OF ISOCITRATE LYASE

AND MALATE SYNTHASE FROM A. faecalis C16

\begin{tabular}{|c|c|c|}
\hline & Isocitrate lyase & Malate synthase \\
\hline $\begin{array}{l}\text { Specific activity of enzyme } \\
\text { (U/mg) }\end{array}$ & 0.451 & 2.340 \\
\hline Temperature optimum & $30^{\circ} \mathrm{C}$ & $30^{\circ} \mathrm{C}$ \\
\hline pH optimum & 7.7 & 8.0 \\
\hline $\mathrm{K}_{\mathrm{M}}(\mathrm{mM})$ & 1.4 & 2.0 \\
\hline $\mathrm{Mg}^{2+}$ dependence & Yes & Yes \\
\hline
\end{tabular}

As shown in Fig.1, the activities of isocitrate lyase and malate synthase are obviously affected by the $\mathrm{pH}$ value. Isocitrate lyase showed a narrow $\mathrm{pH}$ optimum for activity at $30^{\circ} \mathrm{C}$. Very little activity was detected at $\mathrm{pH} 4$ or 11 , the activity was only $0.096 \mathrm{U} / \mathrm{mg}$ and $0.133 \mathrm{U} / \mathrm{mg}$, respectively. The highest activity was measured at $\mathrm{pH} 7.7$, reached $0.451 \mathrm{U} / \mathrm{mg}$, which was nearly four times than the counterpart of $\mathrm{pH} 4$. The $\mathrm{pH}$ optimum, around 7.7 , is only slightly above the $\mathrm{pH}$ value of the medium. The activity of isocitrate lyase decreased when $\mathrm{pH}$ value above 8 . The second key enzyme of the glyoxylate cycle, malate synthase was strictly affected by the $\mathrm{pH}$ value as isocitrate lyase. However, malate synthase showed a relatively broad activity maximum in the $\mathrm{pH}$ range of 7.0-9.0, the highest activity was measured at $\mathrm{pH} 8$, reached $2.300 \mathrm{U} / \mathrm{mg}$, and only very little activity was detected at $\mathrm{pH} 4.0$ or 11 , the activity was $0.821 \mathrm{U} / \mathrm{mg}$ and $0.843 \mathrm{U} / \mathrm{mg}$, respectively. The $\mathrm{pH}$ optimum is only slightly above the $\mathrm{pH}$ optimum of isocitrate lyase.

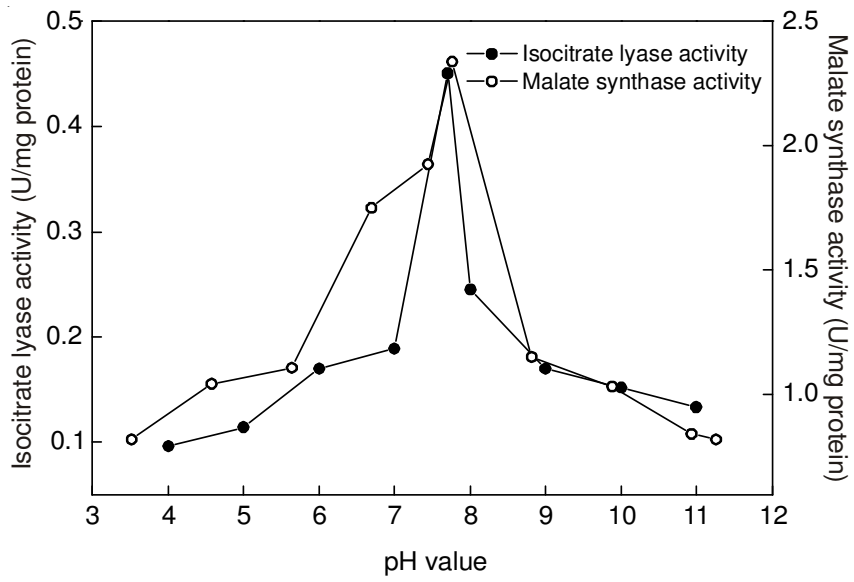

Fig.1. $\mathrm{pH}$ dependence of isocitrate lyase and malate synthase activity

The influence on the activities of isocitrate lyase and malate synthase by the $\mathrm{pH}$ value are surprisingly similar. The activities of the two key enzymes were inhibited in the conditions of too acidic or alkaline. High activities of the two enzymes were detected in the condition of neutral to slightly alkaline. The highest activity of isocitrate lyase was detected at $\mathrm{pH} 7.7$, and the counterpart of malate synthase was detected at $\mathrm{pH}$. The optimum $\mathrm{pH}$ of the two enzymes were closely with the optimum growth $\mathrm{pH}$ of strain A. faecalis C16.

The glyoxylate cycle key enzymes activity were measured in the temperature range of $10-90^{\circ} \mathrm{C}$ (Fig. 2). Isocitrate lyase showed a narrow temperature optimum for activity at $30^{\circ} \mathrm{C}$, coinciding with the optimum growth temperature of this organism. Little activity was found above $70^{\circ} \mathrm{C}$ or below $20^{\circ} \mathrm{C}$. The activity was only $0.137 \mathrm{U} / \mathrm{mg}$ and $0.067 \mathrm{U} / \mathrm{mg}$, at 10 and $90{ }^{\circ} \mathrm{C}$, respectively. The highest activity was $0.522 \mathrm{U} / \mathrm{mg}$, measuring at $30{ }^{\circ} \mathrm{C}$. While malate synthase showed a broad activity maximum in the temperature range of $20-50{ }^{\circ} \mathrm{C}$. The temperature optimum for the reaction was also approximately $30{ }^{\circ} \mathrm{C}$, coinciding with the optimum growth temperature of the organism. The activity reached $2.265 \mathrm{U} / \mathrm{mg}$ at $30^{\circ} \mathrm{C}$. Similar with isocitrate lyase, very little activity was found above $70{ }^{\circ} \mathrm{C}$ or below $20^{\circ} \mathrm{C}$. The activity was only $0.903 \mathrm{U} / \mathrm{mg}$ and 0.156 $\mathrm{U} / \mathrm{mg}$, at $10^{\circ} \mathrm{C}$ and $90^{\circ} \mathrm{C}$, respectively.

As shown in Fig. 2, the activities of isocitrate lyase and malate synthase were obviously affected by the temperature. Isocitrate lyase reaction response more sensitive to the temperature change than the malate synthase. However the optimum temperature of the two enzymes were both $30^{\circ} \mathrm{C}$. When the temperature was low, the reaction rate was relatively low, as the temperature rose, the reaction rate increased accordingly. The maximum activity of the two enzymes were detected at $30{ }^{\circ} \mathrm{C}$. When the temperature was further increased, the reaction rate decreased due to the enzyme protein denatured gradually.

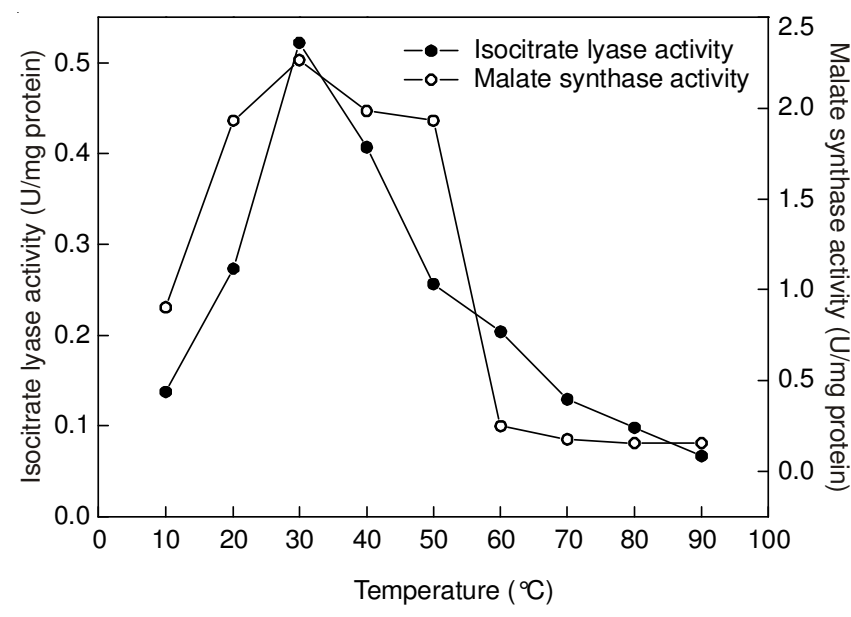

Fig. 2. Temperature dependence of isocitrate lyase and malate synthase activity

The dependence of isocitrate lyase and malate synthase activity on the concentrations of its substrates was measured. showed in Figs. 3 and 4. According to Fig. 3, an apparent $\mathrm{K}_{\mathrm{m}}$ value of $1.4 \mathrm{mM}$ for DL-isocitrate was determined from Michaelis-Menten equation of the data. When the concentration of DL-isocitrate was low, the isocitrate lyase activity was low. As the concentration of DL-isocitrate increase, the enzyme activity increased accordingly. The maximum activity of isocitrate lyase was detected when the concentration of its 
substrate was $1.75 \mathrm{mM}$, the activity reached $0.470 \mathrm{U} / \mathrm{mg}$. But when the substrate concentration continued to increase, the activity of isocitrate lyase began to decline. It seems that high concentration of DL-isocitrate result the isocitrate lyase partially inactivated, and the total activity decreased. And the ICL reaction products were glyoxylate and succinate, the product accumulation inhibited the enzyme activity, As known, isocitrate lyase is significantly inhibited by the succinate analogues $^{31}$.

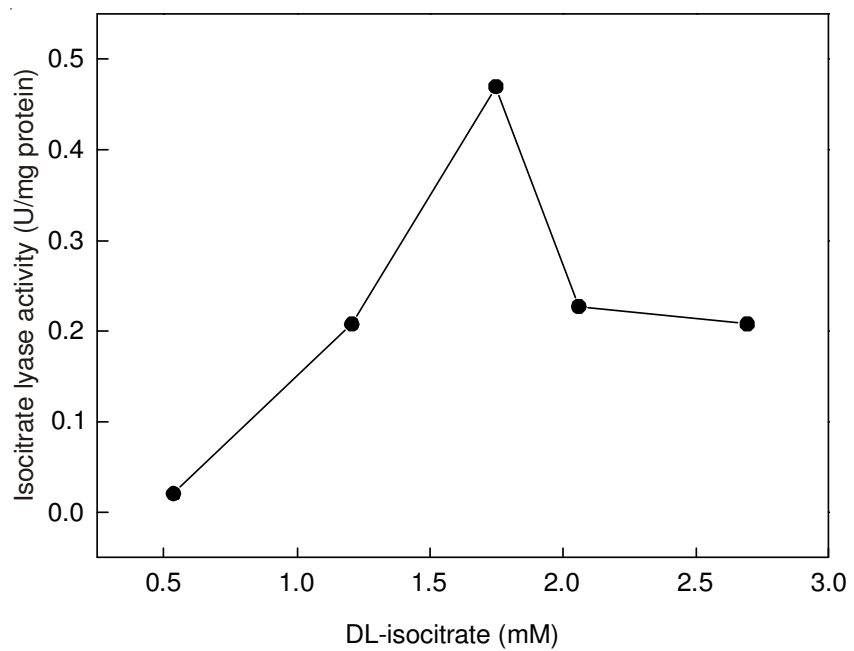

Fig. 3. Dependence of isocitrate lyase activity on the concentration of DLisocitrate

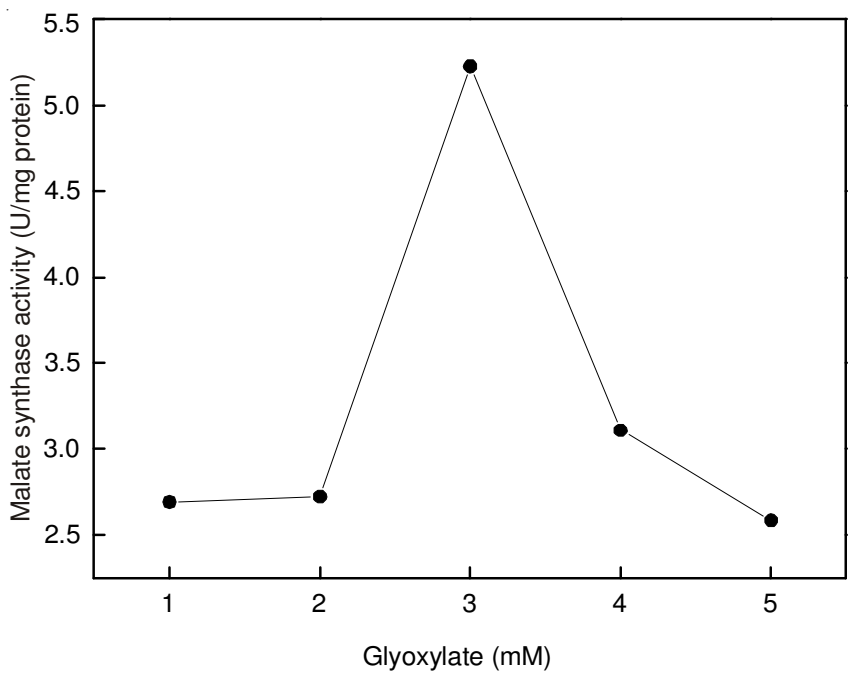

Fig. 4. Dependence of malate synthase activity on the concentration of glyoxylate

While malate synthase presented an apparent $\mathrm{Km}$ value of $2.0 \mathrm{mM}$ for glyoxylate (Fig. 4). Similar with isocitrate lyase, the activity of malate synthase was strictly affected by the concentration of its substrate. The maximum activity of malate synthase was detected when the concentration of glyoxylate was $3.0 \mathrm{mM}$, the activity was $5.228 \mathrm{U} / \mathrm{mg}$. High or low substrate concentration would make the enzyme activity decreased, which was surprisingly similar with isocitrate lyase.

Effect of different carbon sources: To find the influence of carbon source on the nitrogen removal performance and glyoxylate cycle for heterotrophic nitrification bacteria. The isolated strain, A. faecalis $\mathrm{C} 16$, was cultured in the chemically defined medium mentioned above with the substitution of sodium citrate by different carbon sources at the same moles of carbon. In the medium, the amount of $\left(\mathrm{NH}_{4}\right) \mathrm{SO}_{4}$ (as sole nitrogen source) was fixed, providing $100 \mathrm{mg} / \mathrm{L} \mathrm{NH}_{4}{ }^{+}-\mathrm{N}$. And glucose, glycerol, ethanol, succinic acid, fumaric acid, pyruvate, sodium citrate, malic acid, sodium acetate or sucrose as the sole carbon source, $\mathrm{C} / \mathrm{N}$ ratio was 14 . Strain $\mathrm{C} 16$ was incubated at $30{ }^{\circ} \mathrm{C}$ under aerobic condition on a rotary shaker at $120 \mathrm{rpm}$. The fact that the ammonium removal ability of heterotrophic bacterium is strongly influenced by carbon sources have been confirmed ${ }^{18}$. The growth and nitrification of strain $\mathrm{C} 16$ with different carbon sources were showed in Fig. 5.

Shown in Fig. 5, the $\mathrm{OD}_{600}$ values presented that strain C16 grew better in the medium with fumaric acid, malic acid, pyruvate and succinic acid as sole carbon source, and failed to grow on the medium with sucrose, glycerol, glucose or ethanol as sole carbon source. The biomass of strain $\mathrm{C} 16$ was highest when fumaric acid as the sole carbon source and the highest ammonium removal was detected, reached $91.2 \%$. However, when sodium acetate as sole carbon source, the $\mathrm{OD}_{600}$ value was low, and the removal rate of ammonium was low, only $23.3 \%$. The results showed that organic carbon sources are required to process necessary energy during the growth of heterotrophic nitrification bacteria for its growth and nitrification. But some organic carbon cannot be used as the carbon source for the growth of strains. The possible explanation for the difference in energy from different carbon sources are required for different strains to synthetic their own material and nitrification.

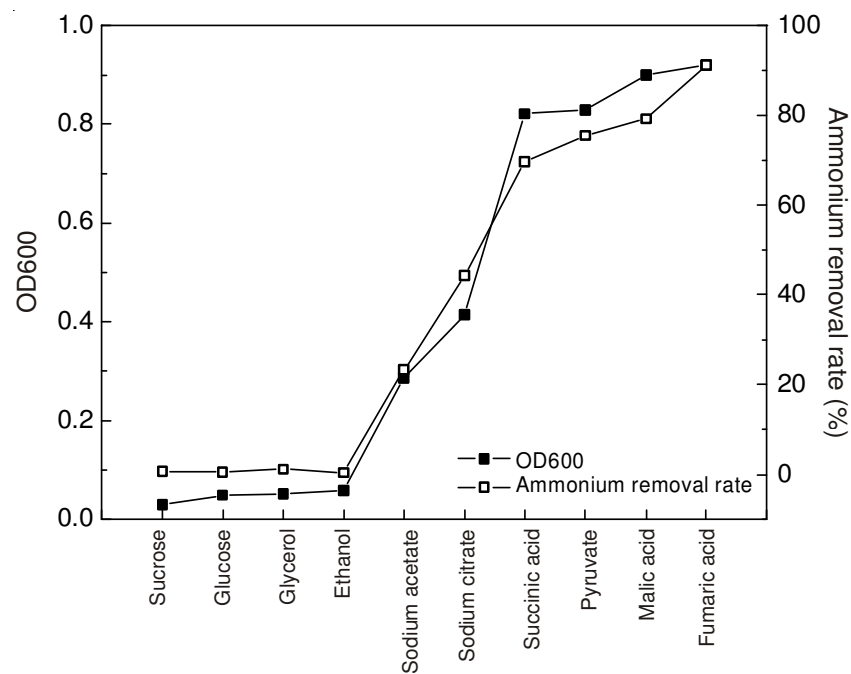

Fig. 5. Effects of carbon sources on the growth and nitrification by strain C16

Relationship between heterotrophic nitrification and glyoxylate cycle: The thalli was harvested in the logarithmic growth phase for measuring the activities of the two key enzymes of glyoxylate cycle and the ammonium removal ability (Fig. 6). The key enzymes activities of the glyoxylate cycle were also strictly affected by different carbon sources. Fumaric acid was the optimum carbon source for growth and nitrification by strain $\mathrm{C} 16$, and the maximum activity of the 
two key enzymes of glyoxylate cycle was detected, accordingly. The activity of isocitrate lyase and malate synthase was $0.736 \mathrm{U} / \mathrm{mg}$ and $2.286 \mathrm{U} / \mathrm{mg}$, respectively. There was a well correlation between the gloxylate cycle enzymes and ammonia nitrogen removal rate by strain $\mathrm{C} 16$. In the medium with different carbon sources, the two enzymes activities of the glyoxylate cycle were different. However, when the high activities of the two key enzymes were detected, the strain C16 showed a high ammonium removal ability, accordingly. The results showed that glyoxylate cycle could have a positive effect on nitrification of strain $\mathrm{C} 16$.

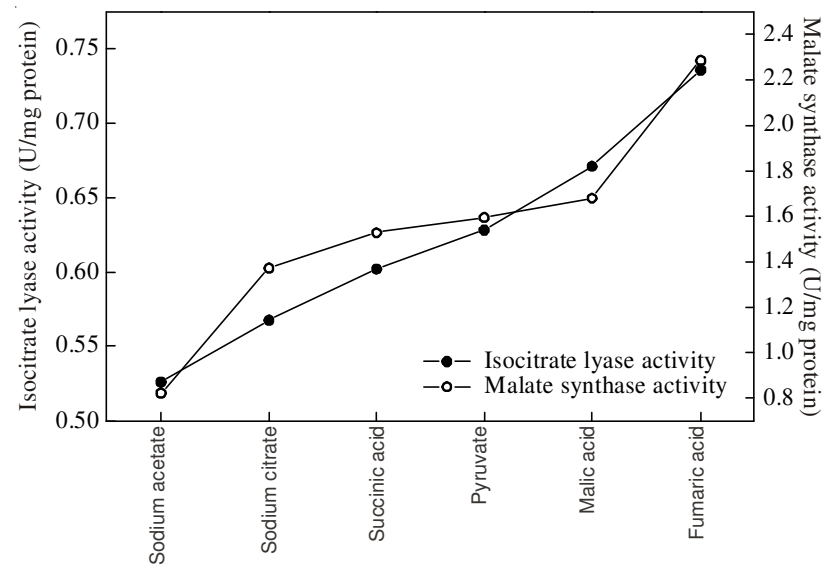

Fig. 6. Effects of carbon sources on the key enzyme activities of glyoxylate cycle by strain $\mathrm{C} 16$

In order to further explore the relationship between the performance of nitrogen removal and glyoxylate cycle, the 4 carbon sources including sodium citrate, succinic acid, pyruvate and fumaric acid were used as the sole carbon source respectively, the activities of hydroxylamine oxidoreductase, nitrate reductase, and nitrite reductase were detected. The results (Fig. 7) showed that although the ammonium removal rate was highest when fumaric acid as carbon source, the specific nitrifying activity was low, the activity of hydroxylamine oxidoreductase, nitrate reductase, and nitrite reductase was only $0.00076 \mathrm{U} / \mathrm{mg}, 0.00833 \mathrm{U} / \mathrm{mg}$ and $0.00801 \mathrm{U} / \mathrm{mg}$, respectively. The specific nitrifying activity was highest when pyruvate as sole carbon source, the activity of hydroxylamine oxidoreductase, nitrate reductase, and nitrite reductase was $0.00563 \mathrm{U} / \mathrm{mg}$,

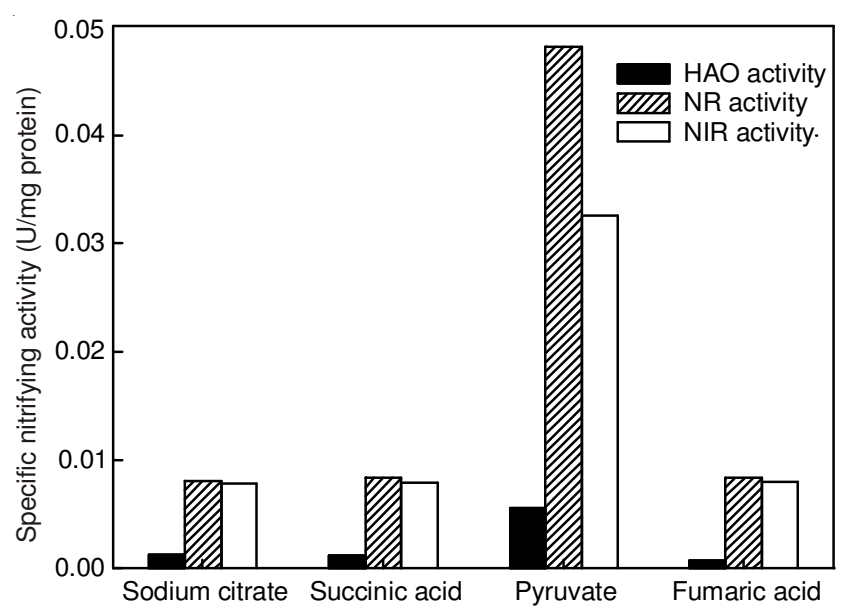

Fig. 7. Effects of carbon sources on the specific nitrifying activity by strain $\mathrm{C} 16$
$0.07817 \mathrm{U} / \mathrm{mg}$, and $0.06251 \mathrm{U} / \mathrm{mg}$, respectively, which is almost ten-fold than fumaric acid, while the ammonium removal rate was $75.5 \%$, which is slightly lower than fumaric acid. The removal rate of ammonium was $69.7 \%$ and $44.2 \%$ when succinic acid and sodium citrate as sole carbon source, respectively, while the specific nitrifying activities were roughly the same. The results presented that the specific nitrifying activity was strongly influenced by carbon source, however no significant relationship was found between either the ammonium removal rate or the glyoxylate cycle and the specific nitrifying activity. A possible explanation is that the ammonium removal rate is strictly dependent on the growth of heterotrophic nitrification bacterium, and the growth of strain was strongly influenced by the glyoxylate cycle.

\section{Conclusions}

- The growth of heterotrophic nitrification bacterium was strongly influenced by the carbon source, and strain C16 showed different adaptability with different carbon sources. The biomass of strain C16 was highest when fumaric acid as the sole carbon source, the $\mathrm{OD}_{600}$ value reached $91.2 \%$. While strain $\mathrm{C} 16$ failed to grow on the medium with sucrose, glycerol, glucose or ethanol as sole carbon source.

- The ammonium removal rate was strictly dependent on the carbon sources. There was a well correlation between the ammonium removal rate and the growth of heterotrophic nitrification bacterium. The ammonium removal rate was high when the growth of strain C16 was well.

- The activities of the two key enzymes of glyoxylate cycle were strongly influenced by carbon source. The highest activities of isocitrate lyase and malate synthase were detected when fumaric acid as the sole carbon source. And there was a well correlation between the ammonium removal rate and activities of the two key enzymes of glyoxylate cycle.

- The specific nitrifying activity was affected by carbon sources, while no significant relationship was found between either the ammonium removal rate or the glyoxylate cycle and the specific nitrifying activity. The ammonium removal rate is strictly dependent on the growth of heterotrophic nitrification bacterium, and the glyoxylate cycle could have a positive effect on the growth of strain C16.

\section{ACKNOWLEDGEMENTS}

This study was supported by the National Natural Scientific Foundation of China (No.51078252), International Cooperation Projects of Shanxi Province (2010081018) and Nature Science Foundation of Shanxi Province (2010011016-1).

\section{REFERENCES}

1. B. Zhao, Q. An, Y.L. He and J.S. Guo, Bioresour. Technol., 116, 379 (2012).

2. D.H. Wen and X.Y. Tang, Environ. Pollut. Control., 25, 283 (2003).

3. J.J. Liu, P. Wang and H. Wang, Res. Environ. Sci., 21, 121 (2008).

4. K.P. Witzel and H.J. Overbeck, Arch. Microbiol., 122, 137 (1979).

5. D.D. Focht and W. Verstraete, Adv. Microb. Ecol., 1, 135 (1977).

6. D. Castignetti and T.C. Hollocher, Appl. Environ. Microbiol., 47, 620 (1984).

7. L.A. Robertson, R. Cornelisse, P. Vos, R. Hadioetomo and J.G. Kuenen, Antonie van Leeuwenhoek, 56, 289 (1989).

8. T.-O. Watsuji, N. Takaya, A. Nakamura and H. Shoun, Biosci. Biotechnol. Biochem., 67, 1109 (2003). 
9. Y. Lin, H.N. Kong, R.Y. Wang, C.J. Li, L. Yan and Y.L. He, Environ. Sci., 29, 3291 (2008).

10. Y. Lü, X. Wang, B. Liu, Y. Liu and X. Yang, Chin. J. Chem. Eng., 20, 995 (2012)

11. E. Brierley and M. Wood, Soil Biol. Biochem., 33, 1403 (2001).

12. M. Nakazawa, T. Minami, K. Teramura, S. Kumamoto, S. Hanato, S. Takenaka, M. Ueda, H. Inui, Y. Nakano and K. Miyatake, Comp. Biochem. Physiol. B Biochem. Mol. Biol., 141, 445 (2005).

13. H. Kornberg and H. Krebs, Nature, 179, 988 (1957).

14. J.A. Serrano, M. Camacho and M.J. Bonete, FEBS Lett., 434, 13 (1998).

15. S. Hüttner, D. Mecke and K.U. Fröhlich, Gene, 188, 239 (1997).

16. H. Kornberg, Biochem. J., 99, 1 (1966).

17. J.L. Sun, X.H. Li, X.H. Liang and R.X. Zhao, Food Sci., 29, 433 (2008)

18. L.C. Zhang and C.R. Wu, Ind. Water Wastewater, 6, 4 (2012).

19. T. Nishio, T. Yoshikura, K. Chiba and Z. Inouye, Biosci. Biotechnol. Biochem., 58, 1574 (1994).

20. T. Nishio, T. Yoshikura, H. Mishima, Z. Inouye and H. Itoh, J. Ferment. Bioeng., 86, 351 (1998).
21. H.-S. Joo, M. Hirai and M. Shoda, J. Biosci. Bioeng., 103, 66 (2007).

22. Y.X. Liu, Y. Wang, Q. Li, H. An and Y.K. Lv, J. Taiyuan Univ. Technol., 43, 421 (2012).

23. Y.K. Lv, J.H.Yin, Y.X. Liu and W.Q. Zhang, CIESC. J., 5, 5 (2011).

24. Z.G. Li, Y.M. Luo and Y. Teng, Soil Environmental Microorganisms Study, Beijing, China, pp. 301-310 (2008).

25. B.Z. Zhang, Plant Physiol. Commun., 3, 31 (1988).

26. T. Roche and B. McFadden, Biochem. Biophys. Res. Commun., 37, 239 (1969).

27. T.M. Ching, Plant Physiol., 41, 1313 (1966).

28. J. Cook, J. Eukaryot. Microbiol., 17, 232 (1970).

29. B. Zhao, Y.L. He, J. Huang, S. Taylor and J. Hughes, J. Ind. Microbiol. Biotechnol., 37, 609 (2010).

30. State Environmental Protection Administration of China, Water and Wastewater Monitoring Analysis Method, Beijing, China, pp. 277-279 (2002).

31. H. Uhrigshardt, M. Walden, H. John, A. Petersen and S. Anemüller, FEBS Lett., 513, 223 (2002). 